\title{
Editorial
}

\section{What is Geriatrics?}

Michael Fossel

President of Telocyte, Grand Rapids, MI 49503, USA; E-Mail: michael.fossel@telocyte.com

\section{OBM Geriatrics}

2018, volume 2, issue 1

doi:10.21926/obm.geriatr.1801004
Received: March 20, 2018

Accepted: March 26, 2018

Published: March 28, 2018

\section{What is geriatrics?}

All of us are intuitively aware, and many of us explicitly aware as well, of the meaning of geriatrics as a specialty. After all, most of us practice geriatrics or we have been intimately involved with this area and we know the reality of geriatrics. Or do we? Geriatrics is an oddly illdefined specialty when you look at it more carefully. Some of us practice medicine, some of us practice in the social sciences, and many of us simply do our jobs day-to-day and try to get by. What we share, however, is the heart of geriatrics: not simply willingness, but a passion to help others who are aging. Nor is it simply "aging" in the chronological sense, but rather it is what happens as we age. It is what distinguishes the young newly-adult from the aging older-adult. In keeping with this distinction, our passion is not directed at aging as chronology, but at aging as suffering, fear, pain, disability, and the myriad other problems that arise with increasing frequency as the years grow longer. It's not the years, it the miles.

Geriatrics, by definition, "deals with the health and care of old people". Caring is an essential component of what we do, perhaps THE essential component, one all-too-often forgotten in the day-to-day struggle of our professions, as we are squeezed for time, resources, and ability to help those we care for. Yet, caring is not enough. The urge to help is always appreciated by those we care for, but what of actually improving those same lives? Can we improve the health, the wellbeing, the very function of those we care for? Can we actually improve lives in geriatrics?

Much of what we do is an uphill battle against the growing disability, disease, and risks that accompany the aging process. We strive to control blood pressure, only to see our patients succumb to strokes. We work hard to manage hemoglobin A1C, only to see advancing renal failure. We encourage exercise, good diet, and stress management, only to watch as the slow creep of

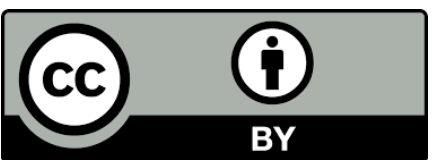

(C) 2018 by the author. This is an open access article distributed under the conditions of the Creative Commons by Attribution License, which permits unrestricted use, distribution, and reproduction in any medium or format, provided the original work is correctly cited. 
Alzheimer's disease as it erases those we care for professionally and, all too often, those we love personally.

Too often, geriatrics becomes a holding action during a bitter retreat from a healthy life. Surely we can do more than fight a holding action. Why not advance instead? We make the assumption that we are all but powerless in the face of aging, that we cannot change the advance of vascular change, the loss of joint surface, the slow evaporation of bony matrix, and the gradual failure of memory and cognition. We think of these as not only facts of medicine, but as facts of life, as though they are part of the very weave of reality, never to be altered.

Perhaps we are wrong.

Aging-related disease has been with human beings as long as we've been human. Thousands of years ago, few of us grew old enough to suffer from the diseases we now associate with aging. Many of us died as children, during childbirth, or from trauma, infection, and the host of diseases that we are still prey to, long before we had the opportunity to grow old. Yet even thousands of years ago, a few of us not only grew old, but we succumbed to age-related disease.

To take one example, Alzheimer's disease was first named more than a century ago. Alzheimers disease, as "Alzheimer's" disease, was first diagnosed in about the same era that modern medicine first began to become "modern" medicine. We have known about the shrunken brain, the amyloid plaques, the dying neurons, and even the tau tangles for a century or so. And yet, despite the advent of modern medicine, pharmaceuticals, and genetics, we still succumb to dementia,

Beyond Alzheimer's and the other dementias, and again despite everything modern medicine offers, we still succumb to a host of other age-related diseases that we lump together as aging and that we still consign to the gentle mercies of geriatrics, and still without cures or even, some would say, without any hope of such cures. Perhaps that hopelessness is not justified. Perhaps our assumptions are the only thing standing between a tired hopelessness and justifiable hopes for a better future.

That age-related disease is caused by cell aging, was first suggested twenty years ago in the medical literature [1] and that same paper suggested that we might be able to use cell aging as a therapeutic target. The notion that cell aging not only caused age-related diseases but could be an effective point of intervention is consistent with everything we know about age-related disease, everything we know about clinical medicine, and everything we know about human aging itself. And yet, even after twenty years, we still succumb to age-related disease.

Can we do better? Can geriatrics make fundamental advances?

Age-related disease is hard for most people, even geriatricians, to understand. The key lies in our assumptions and our fundamental understanding of how aging works at the cellular level. It is this process that has eluded understanding, and largely due to an inability to reexamine our premises, to examine what is really going on within aging cells. The result is that, when we deal with age-related disease, we find that researchers, clinicians, investors, and regulatory agencies all struggle to understand the basic pathology and to find a point of effective intervention.

The obstacle to innovative advances in geriatrics is not aging, but lies in our very assumptions about aging. Innovation only - and always - occurs when you change your assumptions.

Most people, once they overcome their assumptions and look carefully at the diseases with a fresh eye, realize that we not only have the ability to understand them, we have the ability to intervene effectively. To prevent and cure age-related disease takes several things. It requires that we understand the diseases themselves and that we have the right tools to fix the fundamental 
problem. The findings that we take for the diseases themselves are, in reality, no more than symptoms and outcomes of the diseases, rather than fundamental causes of those diseases. Alzheimer's is not simply amyloid plaque, vascular aging is not simply cholesterol and vessel narrowing, osteoporosis is not simply a deficit in mineralization. All of these are no more than biomarkers, symptoms, and findings; they are the culmination of processes that occur at the cellular level and that are already known to be malleable to fundamental interventions. But to intervene effectively takes more than an innovative and sophisticated understanding of cellular aging. It also takes the ability to move from merely understanding to clinical trials. We need to support fundamental, innovative therapies that demonstrate that geriatrics can truly make a difference. We have the ability to provide care and compassion, and we now have the understanding and the tools. We need only move to testing effective clinical interventions.

We need to take our compassion and our intellect and use them to move geriatrics from a holding action into an advance toward better lives.

\section{Competing Interests}

The author has declared that no competing interests exist.

\section{References}

1. Fossel M. Telomerase and the aging cell: implications for human health. JAMA. 1998;279:17321735.

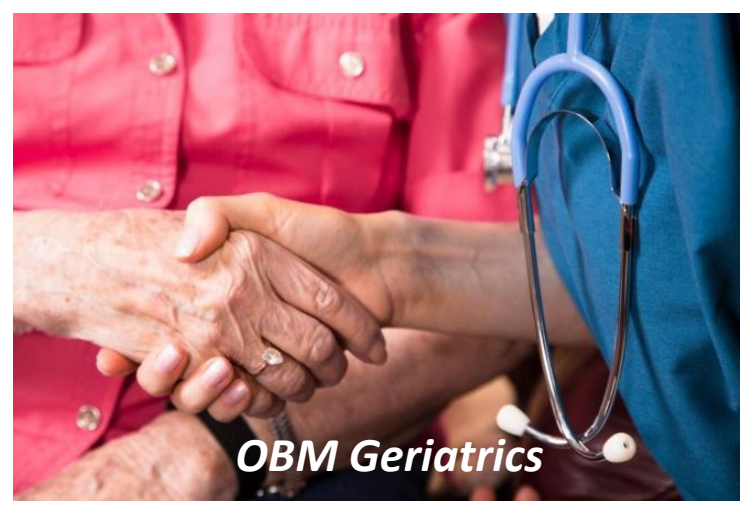

Enjoy OBM Geriatrics by:

1. Submitting a manuscript

2. Joining in volunteer reviewer bank

3. Joining Editorial Board

4. Guest editing a special issue

For more details, please visit: http://www.lidsen.com/journals/geriatrics 